\title{
O norweskiej doktrynie precedensu ${ }^{1}$
}

I. W kulturze prawnej Zachodu zasadniczo wykształciły się dwa podejścia do zapadłych wyroków sądowych (tzw. precedensów). Jedno nawiązuje do koncepcji perswazyjnego precedensu (zwanego również precedensem de facto), o którym to precedensie mówi się, że oddziałuje na rozpoznawanie spraw sądowych w sposób faktyczny, a nie prawny. Z kolei drugie opiera się na instytucji precedensu prawnie wiążącego (określanego także mianem de iure), który uważany jest za źródło obowiązującego prawa, a jego nieprzestrzeganie równoznaczne jest naruszeniu tego prawa. Przy tym doktryna perswazyjnego precedensu przypisywana jest krajom z kręgu civil law, np. Polsce, Niemcom, Włochom czy Francji, natomiast doktryna precedensu wiążącego ma stanowić cechę charakterystyczną dla obszaru common law, a więc przede wszystkim Wielkiej Brytanii oraz Stanów Zjednoczonych. Co więcej, wydaje się, że to właśnie występowanie precedensów de iure stanowi podstawowy wyróżnik anglosaskiego systemu prawa na tle kontynentalnych porządków prawnych (tudzież „sprawczą” przyczynę występowania dalszych odmienności między common a civil law).

Na marginesie warto tu dodać, że prawny obowiązek lub jego brak wzorowania się na poprzednio podjętych decyzjach sądowych (tzw. zasada stare decisis) zdaje się presuponować konkretną ideologię sądowego stosowania prawa. Mianowicie, sędziów można postrzegać jako tych, którzy prawo jedynie deklarują, tj. odnajdująje w zwyczajach, nakazach rozsądku, prawie natury, intencji prawodawcy itp. Przy takim założeniu raz prawidłowo odkryta, przy okazji rozpoznawania danej sprawy, treść (kształt) prawa nie powinna już w przyszłości podlegać zmianom (o ile oczywiście nie zmienił się sam przed-

${ }^{1}$ Do napisania niniejszego artykułu przyczyniły się badania nad norweską doktryną precedensu, które w 2009 r. Autor przeprowadził na Uniwersytecie Tromsø w Norwegii. Projekt został zrealizowany przy wsparciu udzielonym przez Islandię, Liechtenstein i Norwegię, poprzez dofinansowanie ze środków Mechanizmu Finansowego Europejskiego Obszaru Gospodarczego oraz Norweskiego Mechanizmu Finansowego w ramach Funduszu Stypendialnego i Szkoleniowego; wyłączną odpowiedzialność za treść publikacji ponosi autor. 
miot deklarowania, tj. na przykład nie doszło do zmiany zwyczaju lub nowelizacji ustawy), co już samo przez się prowadzi do zachowania konsekwencji w orzekaniu. Można jednak przyjąć, że sędziowie żadnego prawa nie odkrywają - bo takowe obiektywnie czy nawet intersubiektywnie nie istnieje lecz wprost przeciwnie, by rozpoznać konkretny przypadek, nolens volens muszą to prawo dopiero stworzyć. W tym przypadku, aby nakazać organom stosującym prawo rozstrzyganie spraw podobnych w sposób podobny, konieczne jest jakieś dodatkowe uzasadnienie, np. chęć realizacji zasady równego traktowania lub zwiększenia przewidywalności zawartości potencjalnych decyzji sądowych.

W rezultacie o ile za doktryną wiążącego precedensu może stać zarówno deklaratoryjny punkt widzenia, jak i dążenie do zachowania konsekwencji w orzekaniu na skutek świadomie poczynionego wyboru (motywowanego na przykład tym, by zapewnić obywatelom równe traktowanie), o tyle w przypadku doktryny precedensu perswazyjnego pierwsza z tych możliwości odpada. Zezwalając sędziom rozstrzygać identyczne kwestie prawne za każdym razem w sposób odmienny, trudno byłoby jednocześnie utrzymywać, że ich rola sprowadza się wyłącznie do odszukania, a potem odtwórczego zastosowania uprzednio istniejącego prawa. Tutaj rozbieżność rozstrzygnięć oznaczałaby bowiem bądź że sędziowie (lub przynajmniej ich część) z rozmysłem wydają wyroki niezgodne z obowiązującym ich prawem, co z oczywistych względów jest nie do zaakceptowania, bądź że są oni w odnajdowaniu tego prawa nad wyraz nieudolni, co również godzi w zasadność podtrzymywania deklaratoryjnej teorii prawa. Tym samym „oficjalne” przyzwolenie na wydawanie odmiennych wyroków w podobnych stanach faktycznych zaprzecza idei deklarowania prawa; wówczas to sędzia ex definitione staje się twórcą prawa, przynajmniej w wymiarze jednostkowym (każdorazowo na użytek rozpoznawanej przez siebie sprawy). Inną natomiast kwestią jest, że pozytywiści tudzież orędownicy ściśle pojmowanej zasady trójpodziału władzy zacięcie głoszą coś przeciwnego.

Wracając do dwóch znajdujących się na przeciwnych biegunach doktryn sądowego precedensu (cechujących civil i common law), okazuje się, że możliwe jest też rozwiązanie pośrednie, kompromisowe. I to nie tylko jako konstrukt czysto teoretyczny, ale w postaci dającej się spotkać w rzeczywistości. Dokładnie mam tu na myśli casus norweski. W tym skandynawskim kraju udało się bowiem wypracować doktrynę precedensu w swych założeniach wiążącego, a jednocześnie nie aż tak rygorystyczną, jak ma to miejsce na Wyspach i w Stanach Zjednoczonych. W efekcie nie tylko w dziedzinie ustroju ekonomicznego, lecz także systemu prawnego Norwegia zdaje się służyć paradygmatycznym przykładem swoistej trzeciej drogi. 


\section{Ksztalt doktryny precedensu panującej w Norwegii.}

1. Zakres podmiotowy norweskiej stare deisis. Jak już zostało wyżej zaznaczone, w norweskim systemie prawnym, tak jak w common law, ukształtowała się instytucja prawnie wiążącego precedensu sądowego. Co jednak trzeba od razu podkreślić, za powszechnie wiążące uchodzą w Norwegii wyłącznie orzeczenia wydane przez tamtejszy Sąd Najwyższy; przymiotu takiego pozbawione są natomiast, odmiennie niż ma to miejsce w Wielkiej Brytanii oraz USA, wyroki sądów apelacyjnych, nie wspominając już o orzeczeniach sądów jeszcze niższych instancji. W efekcie rozstrzygnięcia pochodzące od innych sędziów niż ci zasiadający w sądzie najwyższej instancji mogą stanowić w Norwegii co najwyżej precedensy de facto (perswazyjne), a nigdy de iure.

2. Modele norweskiego precedensu. W norweskiej doktrynie precedensu, podobnie zresztą jak w anglosaskiej, spotkać możemy dwa konkurencyjne względem siebie ujęcia istoty związania precedensowym wyrokiem: a) sprowadzający precedens do ogólnej reguły, tzw. ratio decidendi, rule-model oraz b) oparty na wnioskowaniu przez podobieństwo model precedensu z analogii.

W przypadku rule-model o obowiązku zastosowania konkretnego precedensu decyduje to, że stan faktyczny rozpoznawanej sprawy odpowiada zakresowi (hipotezie) reguły będącej ratio decidendi danego precedensu; przy czym może to być reguła wyraźnie wskazana przez precedensowego sędziego jako uzasadnienie dla wydanego przezeń wyroku (tzw. ratio wyraźne) bądź też reguła, która, choć niewyartykułowana przez ustanawiającego precedens sędziego, to w domyśle stanowiąca podstawę do wydania precedensowego wyro$\mathrm{ku}$ (tzw. ratio dorozumiane).

$\mathrm{Z}$ kolei w modelu precedensu $\mathrm{z}$ analogii kluczowa rola przypada pojęciu istotnego podobieństwa między sprawą precedensową a sprawami rozstrzyganymi po ustanowieniu precedensu. Ilekroć to podobieństwo zachodzi, sędzia obowiązany jest wydać w przedłożonej mu sprawie wyrok, którego skutki prawne będą odpowiadać skutkom prawnym orzeczonym w precedensowym wyroku; w razie zaś braku tegoż podobieństwa ma on „wolną rękę”.

3. Ratio decidendi oraz obiter dicta. Sztandarowy dla common law podział na wiążące ratio decidendi i niewiążące obiter dicta nie jest w Norwegii do końca przestrzegany. Istotą tego podziału jest uznanie za wiążącą jedynie takiej reguły - czy to wyraźnie sformułowanej przez precedensowego sędziego, czy tylko domniemanej - która była konieczna do wydania precedensowego wyroku (ratio decidendi). Natomiast wszystkie pozostałe reguły, jakie podał sędzia ustanawiający precedens (w sporządzonym przez siebie uzasadnieniu), niejako z definicji muszą być już uważane za niewiążące, stanowiąc obiter dicta. To samo dotyczy w modelu precedensu $\mathrm{z}$ analogii pro- 
pozycji rozstrzygnięcia innych niż występujący w precedensowej sprawie stanów faktycznych. Zawarte w obiter dicta sugestie i wskazówki, choć niezobowiązujące, służą często cenną pomocą innym sędziom, którzy natkną się na poruszony w nich problem w przyszłości, co też stanowi główny powód ich formułowania.

W Norwegii jednakże rozróżnienie na wiążące ratio i niewiążące dicta pozostaje nieco zaciemnione. Mianowicie, moc starannie opracowanych przez SN obiter dicta równa się tu nieraz mocy samego ratio decidendi lub wprost postrzega się tu takie dicta jako powszechnie wiążące.

4. Distinguishing i overruling. Norweska zasada stare decisis, analogicznie do dzisiejszej angielskiej i amerykańskiej, przewiduje możliwość unieważniania (uchylania) i wyróżniania ustanowionych poprzednio precedensów odpowiednio tzw. overruling oraz distinguishing. Do unieważniania w Norwegii kompetentny jest, z pewnym szczególnym wyjątkiem, o którym będzie mowa niżej, Sąd Najwyższy; natomiast wyróżnić precedens może każdy $\mathrm{z}$ sądów, nawet ten orzekający w najniższej instancji. Podstawowa różnica między tymi dwiema instytucjami przejawia się w tym, że overruling, jak się to obrazowo ujmuje, ,ściera precedens z powierzchni ziemi”, przez co ten traci swoje dotychczasowe obowiązywanie, podczas gdy distinguishing wskazuje jedynie na specyfikę aktualnie rozpoznawanego przypadku, która to specyfika uzasadniać ma odmowę wydania wyroku na podstawie prima facie znajdującego zastosowanie precedensu, bynajmniej nie czyniąc tego precedensu nieobowiązującym (istotę wyróżniania upatruje się często w dysanalogii).

Overruling - podobnie jak distinguishing - dokonywany jest w Norwegii zarówno w sposób wyraźny, jak i dorozumiany. $Z$ tą drugą postacią mamy do czynienia wówczas, gdy norweski Sąd Najwyższy nie wspominawszy, że unieważnia któryś ze swoich poprzednich precedensów, wydaje wyrok sprzeczny z tym precedensem. W zależności od obranego modelu precedensu (zob. pkt 2.2.) o sprzeczności takiej może przesądzać: a) brak możliwości pogodzenia, w tym także za pomocą distinguishing, reguły, będącej podstawą ostatnio zapadłego rozstrzygnięcia, z treścią któregoś z dotychczasowych $\mathrm{ra}$ tiones decidendi (rule-model), b) niemożność pogodzenia sposobu, w jaki została rozpoznana sprawa późniejsza, ze sposobem rozpoznania sprawy wcześniejszej istotnie do tej pierwszej podobnej (model z analogii). Pewną norweską swoistością jest przy tym to, że taki dorozumiany overruling odbywa się tu nieraz „małymi kroczkami”, tj. za pomocą nieznacznych, ale z perspektywy czasu konsekwentnych odstępstw od pierwotnie przyjętych w orzecznictwie rozwiązań. Ponadto, abstrahując już od tego, że sędziów zasiadających w norweskim SN trudno byłoby posądzić o nadużywanie swojego uprawnienia (wszak korzystają z niego niezmiernie rzadko), decyzję w przedmiocie sięgnięcia po overruling - według przepisów ustawy regulującej organizację 
tamtejszego wymiaru sprawiedliwości - podejmują oni w składzie szerszym aniżeli ten, który ustanowił zakwalifikowany do unieważnienia precedens. W konsekwencji w odniesieniu do norweskiej stare decisis można by mówić o szczególnym rodzaju horyzontalnego (w poziomie) związania precedensowym wyrokiem.

Także dorozumiany distinguishing przybiera w Norwegii niekiedy postać nader specyficzną. Mianowicie norweskiemu sędziemu zdarza się nie powiedzieć wprost, że właśnie wyróżnił któryś z precedensów, ale niejako w zamian podać bardziej szczegółowy niż zazwyczaj opis faktów rozpoznanego przez siebie przypadku. Wówczas taki sędzia, pozostawiając innym domyślenie się, że miało miejsce distinguishing (tudzież wyjaśnienie powodów, jakie za nim przemawiały), uławia im nieco to zadanie, drobiazgowo naświetliwszy specyfikę stanu faktycznego wyróżnionej sprawy.

Co natomiast najbardziej znamienne, zgoła odmiennie niż w Wielkiej Brytanii oraz USA, w Norwegii dopuszczalna jest, aczkolwiek tylko w sytuacjach oczywistych, antycypacyjna odmiana overruling. Polega ona na tym, że sędzia z zasady nieuprawniony do unieważniania precedensów, kierując się domniemaną (,zakładaną") wolą sądu władnego dokonać unieważnienia, zanim jeszcze dana sprawa do tego sądu trafi, sam unieważnia znajdujący zastosowanie w rozpoznawanej przez niego sprawie precedens. W rezultacie norweska doktryna precedensu nie jest aż tak rygorystyczna jak jej anglosaska odpowiedniczka. W tej ostatniej bowiem wszelkie próby wyręczania w overruling sądu, który ustanowił precedens, przez sądy niższej instancji spotkały się z miażdżącą krytyką, ostatecznie spełzając na niczym. Podobnie natomiast jak na Wyspach, w Norwegii nie praktykuje się unieważniania z mocą na przyszłość (tzw. prospektywny overruling), tj. z zastrzeżeniem, że dany precedens będzie miał jeszcze zastosowanie w sprawie, przy której rozpoznawaniu doszło do jego unieważnienia. Na unikający retrospektywnego skutku overruling możemy się za to czasem natknąć w Stanach Zjednoczonych.

5. Uzasadnienia sądowe, ich styl, rodzaje i język. Styl, w jakim sporządzane są norweskie uzasadnienia sądowe, pod względem dyskursywności i obszerności nie dorównuje stylowi anglosaskiemu. Norwescy sędziowie, inaczej niż ich angielscy koledzy, nie odznaczają się wielomównością i chęcią dzielenia się swoimi przemyśleniami. Dotyczy to zarówno formułowania wypowiedzi w przedmiocie znaczenia dotychczas ustanowionych precedensów, jak i w temacie zasad rządzących norweską doktryną precedensu (przy czym same te zasady, identycznie zreszta jak w doktrynie anglosaskiej, nie są zdefiniowane w żadnej ustawie, będąc wyłącznie wynikiem wykształcenia się w Norwegii takiej a nie innej praktyki sądowej; jedynym wyjątkiem jest uregulowanie w ramach SN trybu unieważniania precedensów, o którym była mowa wyżej, ale i tu pojawiają się głosy, że to rozwiązanie ustawowe nie rodzi po 
stronie tego sądu ani obowiązku przestrzegania precedensów, ani nie daje mu kompetencji do ich unieważniania, nie ingerując w ,autonomiczny” kształt doktryny precedensu). W efekcie ważna rola w objaśnianiu i systematyzacji precedensowych wyroków przypada w Norwegii przedstawicielom nauki prawa. Zdarza się natomiast, że poczynione przez akademików sugestie są następnie ,autoryzowane” (zatwierdzane) przez judykaturę, co jest dowodem ich merytorycznej poprawności.

Powyższe nie oznacza, że norweskim sędziom, szczególnie tym zasiadającym w sądzie najwyższej instancji, zabrania się, żeby na wyroki, jakie wydaja, wpływ miały ich subiektywne poglądy tudzież oceny. Błędem byłoby jednak również powiedzieć, iż Norwegom udało się zupełnie odciąć od wręcz „ubóstwianej” dawniej deklaratoryjnej teorii prawa (o założeniach tej teorii była mowa w pkt. 1, z tym że głównym przedmiotem odkrycia była w Norwegii nie tyle intencja prawodawcy, ile aktualnie panujące zwyczaje prawne, one też były tu w stanie zmienić każdy akt prawa stanowionego łącznie z postanowieniami „formalnej” konstytucji). Warto natomiast podkreślić, że norweski sędzia z zasady ma nie tylko możliwość zgłoszenia zdania odrębnego odnośnie do sposobu rozstrzygnięcia danej sprawy (sentencji wyroku), lecz uprawniony jest także do podania samego odrębnego uzasadnienia (zbieżnego co do wyni$\mathrm{ku}$, a różniącego się w prowadzącej do niego argumentacji); sędzia ten nie ma też odczuwać jakiegoś większego nacisku na zachowanie jednomyślności w głosowaniu ani na sporządzenie jednego wspólnego uzasadnienia, co stanowi pewną dodatkową zachętę do podejmowania dyskusji i wymiany poglądów między członkami składu orzekającego.

Sam język prawniczy jest w Norwegii bardziej potoczny niż wyspecjalizowany, a przez to i łatwiejszy do zrozumienia dla zwykłych obywateli. Co więcej, w norweskim dyskursie prawnym, m.in. na skutek realizmu skandynawskiego (kierunek filozoficznoprawny) oraz rekrutacji kandydatów na sędziów z różnych środowisk i grup zawodowych, przywoływane są często zdroworozsądkowe argumenty kosztem rozważań metateoretycznych, operujących zawiłymi pojęciami prawnymi o wysokim stopniu abstrakcji.

6. Precedens a norweskie prawo stanowione. W materiach prywatnoprawnych od norweskiego sędziego nie wymaga się w każdym przypadku przytoczenia przepisu prawa stanowionego na podstawę prawną wydanego wyroku. Precedensy w obszarze norweskiego prawa cywilnego mogą być zatem ustanawiane bez jakiegokolwiek nawiązania do postanowień ustaw, konstytucji czy aktów wykonawczych. W rezultacie, jak w systemie anglosaskim, również w Norwegii istnieją dogodne warunki do kształtowania się „prawdziwego" case-law, tj. prawa opartego nie na tekstach aktów prawnych, lecz na sposobie, w jaki w przeszłości rozstrzygnięto poszczególne sprawy sądowe. 
Zgoła odmiennie kwestia obowiązku wskazania przepisu prawa stanowionego jako podstawy wydawanego wyroku i tym samym ustanawianego precedensu przedstawia się w norweskim prawie karnym i administracyjnym. Podstawą skazania może być bowiem w Norwegii wyłącznie „paragraf” ustawy karnej (obowiązuje tu zasada nullum crimen sine lege). W konsekwencji precedensy w norweskim prawie karnym, choć mogą w sposób wiążący interpretować postanowienia tego prawa, to jednak muszą być zawsze zakotwiczone $\mathrm{w}$ prawie stanowionym. Podobnie rzecz się ma w nakładającym ograniczenia i ciężary na obywateli norweskim prawie publicznym.

Oczywistym pozostaje natomiast, że tak w Norwegii, jak i w krajach common law sędzia związany jest przepisami prawa stanowionego, ilekroć tylko te zostały w danej materii wydane. W takim też sensie można mówić o prymacie prawa stanowionego nad prawem precedensowym. Jak jednak łatwo zauważyć, w przypadku wyroków (precedensów) stanowiących interpretację postanowień norweskiej tudzież amerykańskiej konstytucji prymat ten może okazać się czysto teoretyczny.

7. Norweski Sąd Najwyższy (Hoyesterrett). Na tle jego brytyjskiego odpowiednika norweski Sąd Najwyższy wydaje się być bardziej sądem III instancji niż tzw. sądem stricte precedensowym, tj. orzekającym tylko wówczas, gdy zachodzi potrzeba ustanowienia nowego lub zmiany dotychczasowego precedensu. W efekcie w Norwegii łatwiej niż w Wielkiej Brytanii jest wnieść skargę kasacyjną i uzyskać zgodę na przyjęcie jej do rozpoznania (nie znaczy to jednak, że norweski SN nie jest uprawniony do przeprowadzania selekcji kierowanych do niego skarg, pozwalającej mu na mniej lub bardziej arbitralne odrzucenie części z nich bez konieczności zagłębiania się w meritum danej sprawy). Ponadto, co ciekawe, w pewnych okolicznościach wystosowanie kasacji jest $\mathrm{w}$ tym skandynawskim kraju możliwe nawet $\mathrm{z}$ pominięciem postępowania przed sądem apelacyjnym, to znaczy w drodze bezpośredniego odwołania się do SN od wyroku wydanego w I instancji.

Norweskiemu Sądowi Najwyższemu, jako że jest uprawniony do orzekania o zgodności przepisów prawa stanowionego z norweską konstytucją, przypada też funkcja, jaką w krajach civil law zwykły pełnić trybunały konstytucyjne. Aczkolwiek o takiej zgodności lub o jej braku sąd ten władny jest stwierdzać tylko w związku z zawisłą przed nim sprawą i w granicach jej rozpoznawania (czyli in concreto); nie może natomiast tego uczynić w sposób oderwany (in abstracto) - ani z własnej inicjatywy, ani, jak jest to dopuszczalne w przypadku polskiego Trybunału Konstytucyjnego, na wniosek podmiotów lub organów nietoczących uprzednio sporu w jakimkolwiek postępowaniu sądowym.

8. Manipulowanie faktami rozstrzyganej sprawy. Podaje się także, iż aby uniknąć zastosowania wiążącego precedensu, norwescy sędziowie 
skłonni są manipulować faktami rozpoznawanej przez nich sprawy. To znaczy, potrafią oni tak pokierować postępowaniem dowodowym i jego wynikami, ażeby zniekształcić rzeczywisty stan faktyczny i w efekcie móc go ,podciagnąć" pod inny precedens (regułę prawa stanowionego) niż ten, który znalazłby zastosowanie w ,normalnym” toku procedowania. Celem takiego zabiegu jest wydanie, w mniemaniu składu orzekającego, wyroku ,sprawiedliwszego" od tego, jaki dyktuje dla niezniekształconego stanu faktycznego obowiązujące prawo.

Poza manipulowaniem faktami rozstrzyganej sprawy nieobca ma być Norwegii też zbliżona w skutkach praktyka przeformułowywania (reinterpretacji) ustanowionych uprzednio precedensów. Wówczas to wyrokujący sędzia dopuszcza się takiego wypaczenia sensu danego precedensu, aby móc rozstrzygnąc przedłożoną mu sprawę nie w sposób, w jaki rzeczywiście nakazuje ten precedens, ale w sposób przez siebie osobiście pożądany.

III. Trzecia droga. Jak już na samym początku niniejszego artykułu wspomniano, doktryna precedensu występująca w Norwegii plasuje się pomiędzy common a civil law. Co jednak znamienne, dzieje się tak nie dlatego, że przeplata ona rozwiązania raz z doktryny anglosaskiej, a innym razem z doktryny kontynentalnej, ale wskutek wypracowania własnych, godzących te dwie skrajności, unikatowych instytucji.

O wypośrodkowanym charakterze norweskiej doktryny precedensu świadczy przede wszystkim ograniczenie kręgu sądów uprawnionych do ustanawiania wiążących precedensów do samego tylko Sądu Najwyższego. W krajach civil law sądy najwyższej instancji, z wyjątkiem trybunałów konstytucyjnych, uprawnienia do kreowania wiążących precedensów zazwyczaj w ogóle nie mają ${ }^{2}$, a w Wielkiej Brytanii, oprócz Sądu Najwyższego, uprawnienie takie posiadają również sądy apelacyjne.

Po drugie, jak wspomniano w pkt. 2.4., sędzia norweski zasiadający w sądzie niższej instancji może nie zastosować się do wiążącego go precedensu, antycypując zamiar jego unieważnienia w Sądzie Najwyższym. Sędzia anglosaski $\mathrm{w}$ ten sposób postapić już jednak nie może, a sędzia kontynentalny przynajmniej teoretycznie - po to by nie zastosować się do stanowiska sądu najwyższej instancji, niczego antycypować nie musi (wszak w świetle założeń

${ }^{2}$ Notabene, mimo iż orzecznictwo sądów najwyższych cieszy się tam dużym zainteresowaniem i jest w znacznym stopniu w praktyce przestrzegane, również w pozostałych krajach nordyckich: Szwecji, Finlandii, Danii i Islandii nie uświadczy się dzisiaj zasady stare decisis. Dawniej jednak (do XVII w.), jak się wydaje głównie z powodu uwarunkowań politycznych, sprawujący w Islandii obok współdzielonych z królem norweskim a potem duńskim kompetencji ustawodawczych - Islandii funkcje sądu najwyższej instancji Alpingi uciekał się nieraz do tworzenia prawa właśnie za pomocą ustanawiania wiążących precedensów sądowych (dokonywania w formie orzeczeń sądowych powszechnie wiążącej wykładni przepisów rodzimego prawa pisanego). 
porządku prawnego, w jakim orzeka, takim stanowiskiem nie jest on w żaden sposób z punktu widzenia prawa związany).

Po trzecie, równoległe wykorzystywanie wnioskowania z precedensowych reguł (rationes decidendi) oraz rozumowania przez podobieństwo (model precedensu z analogii oraz distinguishing) wydaje się w jakimś sensie łączyć praktykę sędziów amerykańskich, w której poczesne miejsce zajmuje analogia, z manierą typową dla systemów civil law, gdzie zdecydowanie dominuje rule-model, i to jeszcze często bez odgórnego założenia możliwości distinguishing. Znaczy to że, istotę wyroku mającego posłużyć za precedens de facto sprowadza się w tych systemach nieraz do ogólnej, prawie całkowicie wyizolowanej od faktów precedensowej sprawy reguły (w Polsce tzw. teza, we Włoszech massima).

Po czwarte, również odcięcie się od ścisłego podziału na niewiążące obiter dicta i wiążące ratio decidendi (w Norwegii starannie opracowane przez SN dicta mogą się okazać równie wiążące jak reguła stanowiąca podstawę do wydania precedensowego wyroku) sugeruje kurs pośredni. W common law, przynajmniej w teorii, usiłuje się bezwzględnie przestrzegać tego podziału, podczas gdy w systemach kontynentalnych zdaje się on nie odgrywać większego, jeśli jakiegokolwiek, znaczenia (waga polskiej tezy lub włoskiej massimy nie różni się za wiele w zależności od tego, czy bezpośrednio prowadziła do wydania wyroku przy okazji uzasadniania którego ją sformułowano).

Po piąte, pośrodku common i civil law stawia Norwegię obowiązek wskazania przepisu prawa stanowionego jako podstawy wydawanego wyroku, a tym samym ustanawianego precedensu jedynie w prawie karnym i administracyjnym. W Wielkiej Brytanii, gdzie nawet część przestępstw jest zdefiniowana wyłącznie przez case-law, taki wymóg nie obowiązuje wcale, a w systemach kontynentalnych z reguły występuje on zawsze, niezależnie od tego, czy mamy do czynienia z materią publiczno- czy prywatnoprawną.

Również styl norweskich uzasadnień sądowych jako relatywnie dyskursywny i „spersonalizowany” sprawia wrażenie czegoś pomiędzy subsumcyjnym i bezosobowym stylem kontynentalnym a wysoce otwartym i rozwlekłym stylem anglosaskim. Podobnie zresztą rzecz się ma ze względnym przywiązaniem w Norwegii do deklaratoryjnej teorii prawa, która to teoria zdaje się być wciąż wiodącą ideologią sądowego stosowania prawa w krajach civil law, będąc dzisiaj już niemalże zupełnie zarzuconą na gruncie anglosaskim.

Ponadto sam quasi-precedensowy charakter norweskiego Sądu Najwyższego wydaje się przejawem jakiegoś kompromisu. Kontynentalnym sądom najwyższej instancji zdarza się orzekać z wręcz niebotyczną częstotliwością, przez co są one często przeładowane, a nawet sparaliżowane natłokiem rozpoznawanych spraw. Natomiast wyroki Izby Lordów, która do 2009 r. pełniła w Zjednoczonym Królestwie funkcje SN, wydawane były niezmiernie rzadko, żeby nie powiedzieć sporadycznie. 
IV. Optymalny charakter. Na koniec warto zauważyć, że norweskie rozwiązania, o których była mowa w niniejszym artykule, wydają się nie tylko manifestować trzecią wypośrodkowaną drogę, ale w dodatku stanowić swoiste optimum.

Po pierwsze, instytucja prawnie wiążących precedensów zapobiega dowolności w orzekaniu i podejmowaniu odmiennych decyzji sądowych w takich samych lub bardzo do siebie zbliżonych stanach faktycznych. Dzięki zasadzie stare decisis prawo staje się bardziej pewne, jednolite i przewidywalne, co nie tylko ułatwia jego adresatom dobrowolne dostosowywanie się do jego wymagań tudzież planowanie i organizowanie zgodnych z nim przedsięwzięć, lecz także usprawnia pracę sędziów i osób zawodowo zajmujących się doradztwem prawnym. Ci pierwsi moga bowiem szybciej wydawać wyroki w przedłożonych im sprawach bez konieczności rozważania za każdym razem na nowo wszystkich argumentów za i przeciw, jakie można podnieść w danej kwestii prawnej. Adwokaci natomiast nie są skazani na udzielanie swoim klientom porad $\mathrm{w}$ rodzaju, że ,wszystko zależy od wszechmocnego i nieobliczalnego sądu". Związanie precedensem stanowi też bezpośredni wyraz nakazu równego traktowania, podnoszonego współcześnie do rangi tzw. zasady sprawiedliwości formalnej. Bez wattpienia ciężko byłoby twierdzić, że prawo jest jednakowe dla wszystkich, w sytuacji gdy w identycznych okolicznościach sądy wydawałyby skrajnie odmienne wyroki.

Co więcej, przyznanie judykaturze uprawnienia do ustanawiania wiążących precedensów nie tylko nie godzi w zasadę trójpodziału władzy, jak mogłoby się z pozoru wydawać, lecz wprost przeciwnie stanowi warunek sine qua non efektywnej polityki legislacyjnej. Otóż w przypadku gdy uchwalone przez parlament ustawy są niejednolicie (inaczej przez każdy sąd) rozumiane, nie tylko niełatwo jest prognozować, jakie skutki wywołają one w świecie zewnętrznym, ale równie ciężko może być korygować niewłaściwy sposób ich sądowego stosowania - skoro część sędziów interpretuje dany przepis prawidłowo, tj. zgodnie z zamierzeniem prawodawcy, a czesść nieprawidłowo, to niejednokrotnie może być bardzo trudno ustalić, co dokładnie należy w treści tego przepisu zmienić, by uzyskać jego jednakowe, a zarazem pożądane stosowanie, nie doprowadzając jednocześnie do powstania nadmiernej kazuistyki w prawie stanowionym.

Po drugie, ograniczenie kręgu sądów władnych do ustanawiania wiążących precedensów do samego tylko Sądu Najwyższego pozwala na zapewnienie prawu sporej dozy pewności i przewidywalności, nie stwarzając przy tym poważnego zagrożenia dla przejrzystości i jedności w systemie prawa. Biorąc pod uwagę liczbę pozostałych sądów oraz częstotliwość, z jaką wydają one wyroki, nawet tylko te bezpośrednio podległe SN, przyznanie ich orzecznictwu rangi wiążącego precedensu powodowałoby wprowadzenie do obiegu kolosalnej liczby precedensowych reguł, które nie dość, iż byłyby trudne do spa- 
miętania, a nawet odszukania, to jeszcze niewykluczone, że pozostawałyby we wzajemnej sprzeczności. To znaczy, w razie funkcjonowania dwóch lub więcej sądów apelacyjnych każdy z nich mógłby rozstrzygnąć daną kwestię prawną w sposób odmienny, co po nadaniu tym rozstrzygnięciom mocy powszechnie wiążącej oznaczałoby obowiązywanie różnych praw (w poszczególnych okręgach sądowych) w tym samym systemie prawa.

Po trzecie, dopuszczenie do koegzystencji dwóch w pewnym sensie dopełniających się ujęć istoty precedensu, rule-model oraz modelu $\mathrm{z}$ analogii, $\mathrm{z}$ jednej strony wydaje się gwarantować pewność i przewidywalność prawa, a z drugiej zapobiegać „mechaniczności” w jego stosowaniu, która to mechaniczność - jak zdążyła pokazać historia - może doprowadzić do niepowetowanych krzywd i niedorzeczności. Powstawaniu tych ostatnich zdaje się też przeciwdziałać, zachodząca w Norwegii, możliwość wyróżniania i antycypacyjnego unieważniania precedensów. Pierwsze już z samego swojego założenia umożliwia orzekającemu sędziemu potraktowanie bieżącego przypadku w sposób indywidualny, drugie zaś pozwala uniknąć konieczności zastosowania precedensu wyraźnie zdezaktualizowanego tudzież jawnie niesłusznego.

Po czwarte, ze zwiększaniem poznawalności i zrozumiałości prawa dla jego adresatów, co niewątpliwie uznać należy za stan ze wszech miar pożądany, idzie w parze zrozumiały język prawniczy oraz zdroworozsądkowy charakter argumentów używanych w norweskim dyskursie prawnym (oczywiste jest, że aby móc, nawet przy najlepszych chęciach, dobrowolnie stosować się do nakazów obowiązującego prawa, trzeba mieć zagwarantowaną faktyczną możliwość zaznajomienia się z tym prawem). Zaletą mogą się tu też okazać zwięzłe, ale jednocześnie relatywnie szczere uzasadnienia sądowe. Dzięki takim cechom - bez znacznego uszczerbku dla możności dowiedzenia się o tym, co tak naprawdę zdecydowało o takim, a nie innym rozstrzygnięciu danej sprawy - tok zastosowanej w uzasadnieniu argumentacji może być przez innych szybko przyswojony, a identyfikacja wiążącej części precedensowego wyroku, w szczególności jego ratio decidendi, znacznie ułatwiona.

Po piąte, charakteryzujący Norwegię brak obowiązku wskazania przepisu prawa stanowionego jako podstawy prawnej wydanego w obszarze prawa prywatnego wyroku nie wymusza, tak jak w wielu krajach civil law, utrzymywania za wszelką cenę fikcji, że z często ogólnych, niedookreślonych, w zasadzie pozbawionych jakiejkolwiek treści albo antytetycznych postanowień ustaw cywilnoprawnych „logicznie” wynikają jakieś konsekwencje prawne dla konkretnych stanów faktycznych. Fikcja ta, choć może i wygodna dla osób będących sędziami (nieporozumieniem byłoby wiązanie z nimi odpowiedzialności za zapadłe wyroki, skoro o treści tych wyroków, „spętawszy ręce” organom stosującym prawo, z góry przesądził ustawodawca), zdaje się dziś zbyt łatwa do zdemaskowania, $i$ to nie tylko ze strony profesjonalnych prawników, lecz także zwykłych obywateli. W rezultacie jej uporczywe, „oficjalne” podtrzy- 
mywanie może nie budować, ale podkopywać, i to znacznie, autorytet wymiaru sprawiedliwości.

Również przyzwolenie na kreowanie w Norwegii wiążących reguł prawnych poza kategorią rationes decidendi, tj. w kwestiach prawnych, których rozstrzygnięcie nie było konieczne do rozpoznania precedensowej sprawy, jawi się jako trafne posunięcie. Sprzyja ono bowiem rozwojowi prawa i dostosowywaniu go do aktualnych warunków społeczno-polityczno-gospodarczych (szybkiemu reagowaniu na zmiany, jakie nieustannie dokonują się w pozaprawnej rzeczywistości). A ponadto umożliwia na bieżąco, bez czekania, aż objęta nimi sprawa trafi do sądu, autorytatywnie usuwać narosłe na tle obowiązującego prawa wątpliwości. Przez wzgląd na pewność i przejrzystość w systemie prawa postulować by tu tylko należało, aby wola sądu, że któraś z podanych przez niego reguł niekwalifikujących się na ratio decidendi ma stanowić powszechnie obowiązujące prawo, była wyraźnie uzewnętrzniana.

Podobnie połowicznie precedensowy charakter norweskiego SN wydaje się być rozwiązaniem bliskim ideału. Przy takim układzie, inaczej niż wyglądałoby to w przypadku sądu III instancji, sędziowie orzekający w sądzie najwyższej instancji mogą odrzucić a limine część wnoszonych do nich skarg, nie będąc zmuszonymi do wydawania rozstrzygnięć w pośpiechu i „psucia” w ten sposób precedensowego prawa (mają wystarczającą ilość czasu do namysłu przed podjęciem decyzji co do zmiany dotychczasowego lub ustanowienia nowego precedensu). A poza tym zapewnione są wówczas warunki do eliminacji wyroków, w których sąd apelacyjny dopuścił się jawnej niesprawiedliwości, tudzież wydanych z pogwałceniem przepisów prawa stanowionego lub prawnie wiążących precedensów, a uchylenie których to wyroków nie rodzi potrzeby ani wprowadzenia nowego precedensu, ani unieważnienia któregoś z obecnie obowiązujących precedensów (co wychodzi poza zakres kognicji sądu stricte precedensowego). Wśród instytucji zasługujących na uznanie nie powinno się też pomijać procedury przewidzianej dla dokonywania overruling wewnątrz norweskiego SN (składy powiększone): zapobiegając nazbyt częstym i łatwym zmianom (woltom) w orzecznictwie sądu wyposażonego w kompetencje prawotwórcze, zdaje się ona przeciwdziałać pochopności w tworzeniu sądowego prawa, tym samym wzmacniać jakość i stabilność tego prawa; a także występującej w Norwegii możliwości wniesienia kasacji z pominięciem postępowania przed sądem apelacyjnym, która to możliwość, przyspieszając dokonywanie ,palących” reform w prawie oraz rozwiewanie powstałych lub mogących powstać na tle prawnym niejasności, jest się w stanie przysłużyć zarówno pewności prawa, jak i jego elastyczności.

Powyższe nie prowadzi jednak do konkluzji, że o wszystkich aspektach doktryny precedensu panującej w Norwegii należy wypowiedzieć się pozytywnie. Manipulowanie faktami rozpoznawanej sprawy, przeformułowywanie precedensów, brak miejsca dla prospektywnego overruling czy też małomów- 
ność norweskich sędziów, w tym zwłaszcza w przedmiocie zasad rządzących tamtejszym precedensem, nie służą ani zrozumiałości i obliczalności prawa, ani niemożliwej do osiagnnięcia bez tych dwóch sprawiedliwości, w zamian za to podważają wiarę stron w uczciwość procesu sądowego oraz instytucję prawa jako takiego.

Podsumowując ten zarys, należy stwierdzić dość intrygującą postać doktryny precedensu. Mimo obecności prawnie wiążących precedensów doktryna norweska nie jest bowiem aż tak rygorystyczna jak jej anglosaska odpowiedniczka, co w rezultacie sprawia, iż równie blisko jest jej do systemu common, jak i civil law. Ponadto, co nawet ważniejsze, rozwiązania składające się na doktrynę norweską zdają się - często w stopniu aż nie do uwierzenia rozsądne. Pretendują mianowicie do bycia złotym środkiem pomiędzy daleko posuniętym skrępowaniem sędziego anglosaskiego a swobodą jego kontynentalnego kolegi - tym samym między pewnością i przewidywalnością prawa z jednej strony a jego słusznością i elastycznością ze strony drugiej.

\section{Wybrana literatura}

I. Odnośnie do systemu sądownictwa w Norwegii oraz norweskiej doktryny precedensu:

Courts of Norway, http://www.domstol.no/upload/DA/Internett/da.no/Publikasjoner/Domstolene\% 20i\%20Norge_ENG_OPPSL.pdf.

S. Eng, Precedent in Norway, w: Interpreting Precedents. A Comparative Study, pod red. D.N. MacCormicka i R.S. Summersa, Dartmouth 1997, s. 189-217.

S. Eng, The Doctrine of Precedent in English and Norwegian Law - Some Common and Specific Features, „Scandinavian Studies in Law” 2000, t. 39, s. 275-323.

W.E. Eyben, The Attitude Towards Judicial Precedent in Danish and Norwegian Courts, „Scandinavian Studies in Law" 1959, t. 3, s. 55-86.

P. Hagelien i M. Vonen, The Norwegian Legal System: an Introductory Guide, Bergen 1994.

T. Leivestad, Custom as a Type of Law in Norway, „Law Quarterly Review” 1938, t. 54, nr 213 i 214, s. $95-115$ i $266-286$.

H. Lindblom, The Role of the Supreme Courts in Scandinavia, „Scandinavian Studies in Law”2000, t. 39 , s. 325-366.

L.B. Orfield, The Growth of Scandinavian Law, Philadelphia 1953.

A. Rosseland, Presentation of the National Courts Administration and the Norwegian Court Reform of 2002, „Scandinavian Studies in Law”, 2007, t. 51, s. 608-628.

II. Odnośnie do anglosaskiej doktryny precedensu i sytemu sądownictwa Stanów Zjednoczonych oraz Wielkiej Brytanii:

L. Alexander, Precedent, w: A Companion to Philosophy of Law and Legal Theory, pod red. D. Pattersona, Blackwell Publishing Ltd 1996, s. 503-513.

Z. Bankowski, D.N. MacCormick, G. Marshall, Precedent in the United Kingdom, w: Interpreting Precedents. A Comparative Study, pod. red. D.N. MacCormicka i R.S. Summersa, Dartmouth 1997, s. 315-354.

Z. Bankowski, D.N. MacCormick, L. Morawski, A.R. Miguel, Rationales for Precedent, w: Interpreting Precedents. A Comparative Study, pod red. D.N. MacCormicka i R.S. Summersa, Dartmouth 1997, s. 481-501.

R. Cross, Precedent in English Law, Oxford 1968. 
M. Koszowski, Anglosaska doktryna precedensu. Porównanie z polska praktykq orzecznicza, Warszawa 2009.

G. Lamond, Precedent and Analogy in Legal Reasoning, w: Stanford Encyclopedia of Philosophy, 2006, http://plato.stanford.edu/entries/legal-reas-prec.

E.H. Levi, An Introduction to Legal Reasoning, Chicago 1949.

G. Marshall, What is Binding in a Precedent, w: Interpreting Precedents. A Comparative Study, pod red. D.N. MacCormicka i R.S. Summersa, Dartmouth 1997, s. 503-517.

R.S. Summers, Precedent in the United States (New York State), w: Interpreting Precedents. A Comparative Study, pod red. D.N. MacCormicka i R.S. Summersa, Dartmouth 1997, s. 355-406. 